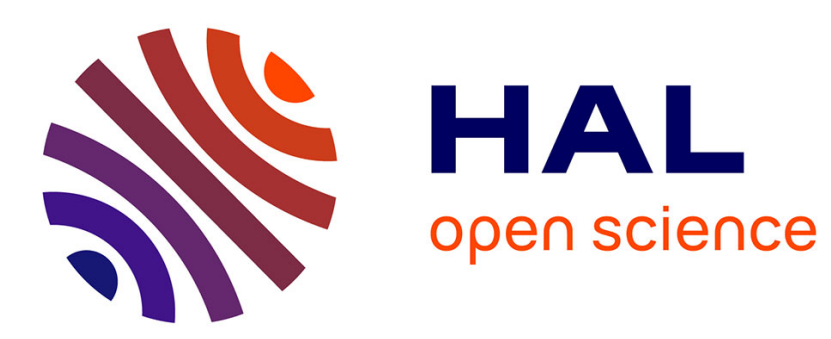

\title{
Industrial Symbiosis - an environmental perspective on regional development
}

\author{
Pauline Deutz, Donald Lyons
}

\section{To cite this version:}

Pauline Deutz, Donald Lyons. Industrial Symbiosis - an environmental perspective on regional development. Regional Studies, 2008, 42 (10), pp.1295-1298. 10.1080/00343400802382190 . hal-00514719

\author{
HAL Id: hal-00514719 \\ https://hal.science/hal-00514719
}

Submitted on 3 Sep 2010

HAL is a multi-disciplinary open access archive for the deposit and dissemination of scientific research documents, whether they are published or not. The documents may come from teaching and research institutions in France or abroad, or from public or private research centers.
L'archive ouverte pluridisciplinaire HAL, est destinée au dépôt et à la diffusion de documents scientifiques de niveau recherche, publiés ou non, émanant des établissements d'enseignement et de recherche français ou étrangers, des laboratoires publics ou privés. 


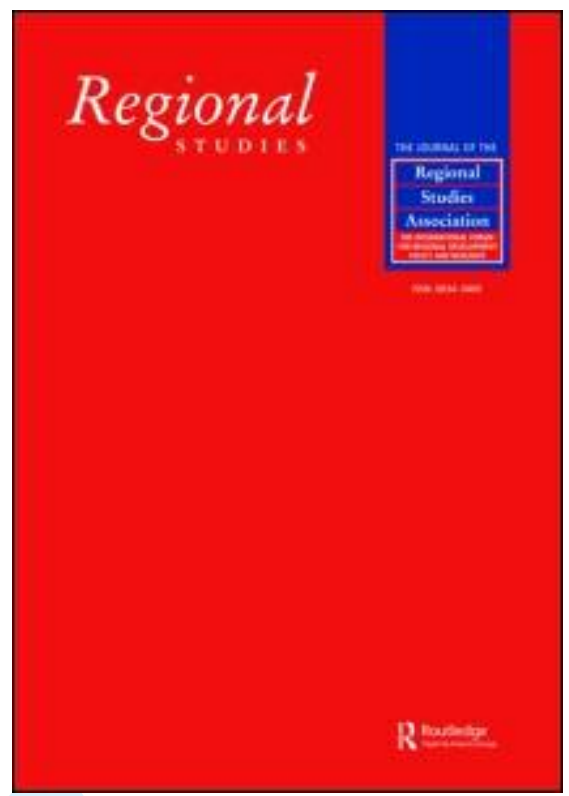

\section{Industrial Symbiosis - an environmental perspective on regional development}

\begin{tabular}{|r|l|}
\hline Journal: & Regional Studies \\
\hline Manuscript ID: & CRES-2008-0133.R1 \\
\hline Manuscript Type: & Main Section \\
\hline JEL codes: & $\begin{array}{l}\text { A14 - Sociology of Economics < A1 - General Economics < A - } \\
\text { General Economics and Teaching, L52 - Industrial Policy } \mid \text { Sectoral } \\
\text { Planning Methods < L5 - Regulation and Industrial Policy < L - } \\
\text { Industrial Organization, O18 - Regional, Urban, and Rural Analyses } \\
\text { < O1 - Economic Development < O - Economic Development, } \\
\text { Technological Change, and Growth, R58 - Regional Development } \\
\text { Policy < R5 - Regional Government Analysis < R - Urban, Rural, } \\
\text { and Regional Economics }\end{array}$ \\
\hline Keywords: & $\begin{array}{l}\text { regional development, industrial symbiosis, agglomeration } \\
\text { economies, transactions, trust, eco industrial parks }\end{array}$ \\
\hline
\end{tabular}

\section{S) ScholaroNE \\ Manuscript Central}




\title{
INDUSTRIAL SYMBIOSIS - AN ENVIRONMENTAL PERSPECTIVE ON REGIONAL DEVELOPMENT
}

Editorial for mini-themed issue of Regional Studies Submitted 10 June 2008 Resubmitted 28 July 2008

\author{
$\underline{\text { Pauline Deutz and Donald Lyons }}$ \\ p.deutz@hull.ac.uk \\ Department of Geography \\ University of Hull \\ HULL \\ HU6 7RX \\ United Kingdom \\ Department of Geography \\ University of North Texas \\ P.O. Box 305279
}

http://mc.manuscriptcentral.com/cres Email: regional.studies@newcastle.ac.uk 


\author{
Denton \\ Texas \\ 76203-5279 \\ United States \\ Phone: 940-565-2721 \\ Fax: 940-369-7550 \\ DLyons@unt.edu
}

http://mc.manuscriptcentral.com/cres Email: regional.studies@newcastle.ac.uk 


\section{INDUSTRIAL SYMBIOSIS - AN ENVIRONMENTAL PERSPECTIVE ON REGIONAL DEVELOPMENT}

With environmental considerations an increasing imperative for regional development, industrial symbiosis' focus on the environmental benefits spatial proximity for industry merits serious attention. Industrial symbiosis, a burgeoning body of academic work, investigates the environmental and economic benefits from real or hypothesised networks of companies engaged in the exchange of material and energy by-products. The mutual relevance of these literatures has been under-appreciated, which has helped to fuel unrealistic expectations for the regional economic development potential of industrial symbiosis initiatives. The three papers in this collection address areas of common interest to the regional development and industrial symbiosis literatures. In this short paper, we will first introduce Regional Studies readers to industrial symbiosis and the field of industrial ecology, to which it belongs. We then summarise each of the papers contributing to the special issue, before presenting some conclusions about the potential overlap between industrial symbiosis and regional development. Finally, we offer some suggestions for future research.

Industrial Ecology (IE) is a collective term for a number of business-centered systemsoriented approaches to improve the eco-efficiency of industry (FROSCH and GALLOPOULOS, 1989; GRAEDEL and ALLENBY, 1995). Employing ecological metaphors, IE asks questions about the sustainability of the current industrial paradigm. In essence, it argues that the traditional model of industrial activity where individual manufacturing processes take in raw materials and generate products to be sold plus waste for disposal, needs to be transformed into a more integrated "closed-loop" model: an industrial ecosystem. Here raw material extraction and 
waste generation are minimized since waste serves as the raw material for other production processes (FROSCH and GALLOPOULOS, 1989).

One sub-field of industrial ecology, industrial symbiosis (IS), is of particular significance to the regional development $(\mathrm{RD})$ community. IS draws its conceptual foundation from the ecological metaphor of biological symbiosis, where unrelated organisms can find mutual benefit through the exchange of by-products. That is, one organism's waste can be another's resource. IS grounds industrial ecology in specific places by emphasizing the synergistic advantages of networks of traditionally separate but geographically proximate companies exchanging byproducts and energy cascades or though the joint provision of utilities and services that improve both their overall environmental and economic performance (CHERTOW, 2000).

Industrial Symbiosis' focus on the synergistic advantages of industrial agglomerations coupled with regional science/economic geography's nascent concern with the relationship between the environment and development, presents a number of overlapping themes of interest (GIBBS, 2003; HUDSON, 2007). Until recently, environmental issues have received little attention from industrial geographers, despite the industrial origins of so many current environmental problems. However, practitioners of regional development are under increasing pressure to address environmental issues (HAUGHTON and COUNSELL, 2004). Similarly, whilst industrial ecologists' envisage industrial ecosystems as networks of proximate firms they have paid little attention to either the theoretical or policy debates on the dynamics and efficacy of industrial clusters as reported in the regional development literature (GIBBS, 2003).

Industrial ecology, and especially IS, progressed rapidly from a novel idea to a policy option in the early 1990s, inspired by the discovery of the complex web of by-product material and energy exchanges among a cluster of companies and the community of Kalundborg, Demark 
(CHERTOW, 2007). For example, the local power station pipes steam to a local biotechnology company which provides surplus yeast to local farmers as pig food, and excess calcium sulfate (industrial gypsum) from the sulfur dioxide scrubbers to a local wallboard company (GERTLER, 1995). These linkages evolved gradually and bilaterally, without an overall design plan or recognition of the environmental implications, as the firms sought to make economic use of their by-products and to minimize the cost of compliance with new environmental regulations. The identification of other IS networks in Styria, Austria (SCHWARZ and STEINIGER, 1997), Jyväskylä, Finland (KORHONEN et al., 1999), and subsequently Puerto Rico (DESCHENES and CHERTOW, 2004), promoted interest in the development of additional bounded IS networks.

Significantly, IS became seen as an economic development tool, as well as an environmental, initiative (e.g., COHEN-ROSENTHAL, 2003). IS networks were hailed as an environmental-business-community win-win-win offering with jobs, profit, and environmental improvement (SCHLARB 2001; LOWE, 2002). Eco-industrial parks (EIPs) were conceived as a means of demonstrating IS by implementing it on a local scale (CHERTOW, 2000). EIPs were initially defined as "a community of manufacturing and service businesses seeking enhanced environmental and economic performance through collaboration in managing environmental and resource issues including energy, water and materials" (LOWE and WARREN, 1996, p 78) within the geographic boundaries of an industrial park. However, in spite of initial enthusiasm and high-level policy support for EIPs empirical evidence of successful IS exchanges has been scant (CHIU and YONG, 2004; GIBBS et al., 2005; OH et al., 2005).

The lack of success in the implementation of IS within EIPs has generated reflection within the IS community (CHERTOW, 1999; DESROCHERS, 2002; VAN LEEUWEN et al., 
2003; HEERES et al., 2004) with cautionary notes being sounded as to the rate of progress that could reasonably be expected at establishing symbiosis. However, the initial aims of IS were clouded by expectations of economic benefits. This and the subsequent disappointment at the concrete economic and environmental results, was fostered by the isolation of the IS literature from mainstream economic development debates and the conditions under which industrial clusters may generate new economic growth.

The papers in this issue situate IS firmly within an RD context. This enables consideration of the lessons of the RD literature for IS, and of both the lessons and limitations of IS as a potential component of sustainable regional development policy. IS represents an emerging form of economic activity, focused in particular on material and energy flows, in an attempt to recover industrial by-products in a profitable way. Given increasing interest in sustainable regional economic development, it is important to consider how these activities interrelate both spatially and sectorally with other forms of economic activity.

Agglomeration economies are a key area of interest in regional development (e.g., PELEGRÍN and BOLANCÉ, 2008). CHERTOW et al. (this volume) examine whether IS practices can produce environmental benefits of co-location distinct from the dimensions traditionally considered in terms of agglomeration economies. The paper examines how the agglomeration economies theorised in the RD literature are expressed in industrial clusters in Puerto Rico. They also examine potential and actual sharing and cycling of resources such as energy, water, and materials amongst the co-located firms. In the terms of CHERTOW (2007), the authors "uncovered" significant existing networks of "kernels" of IS. What makes the observed exchanges a unique form of agglomeration economy is the simultaneous reduction in negative environmental impact and lowering of production costs from the replacement of virgin 
inputs, coupled with local environmental improvement from less waste disposal. These nontrivial benefits were all generated from exchanges between firms in separate economic sectors. The authors extend the theorisation of agglomeration economies to encompass the positive environmental externalities that can accrue in industrial clusters by means of IS.

Another area of overlap between IS and RD relates to clusters and networking (GIBBS, 2003). Given the numerous perspectives on clusters within RD (e.g., BENNEWORTH and HENRY, 2004), DEUTZ and GIBBS (this volume) investigate whether eco-industrial parks (EIPs) are an environmentally explicitly version of an existing approach to $\mathrm{RD}$, or comprise a distinct perspective. The empirical focus of this study is EIPs being developed de novo, in contrast to the pre-existing regional clusters of industries studied in the CHERTOW et al. paper. Using the three meta-themes of external economies of scale, networking and policy, the authors argue on both theoretical and empirical grounds that EIPs should be seen as a distinct cluster perspective. They then investigate the policy implications for IE and RD of recontextualising IE as a cluster perspective. They caution that EIPs are a challenging form of economic development, given that success requires specific types of transactions (physical exchange of byproduct waste and energy). Whereas proximity can reduce transaction costs in other forms of clusters, IS transactions (e.g., finding someone to purchase or simply take a by-product) can be complex than the alternatives (e.g., direct disposal of waste).

The difficulty in overcoming issues of trust and confidentiality in the establishment of synergistic networks or clusters of firms are well known to both the IE and regional development community. However, notwithstanding elaborate theoretical descriptions of the importance of trust to inter-firm transactions, there is little in-depth work on the processes or mechanisms through which trust (or distrust) emerges in particular social or economic contexts (e.g., 
MURPHY, 2006). The final paper, by HEWES and LYONS takes up this topic and presents an ethnographic analysis of the strategies employed by two IS/EIP "champions" to establish the conditions necessary for IS oriented transactions to emerge. The paper asks three questions in relation to their strategies: how the champions developed trust-based social relationships; the importance of the champion being personally located in the community and the longer term viability of EIPs once the champion departs. Whilst the particularities of the two champions' approaches differed, in both cases their key strategy was to build out from individual relationships that were purposely constructed and to leverage those relationships to get broader buy-in from the community.

In conclusion, the evidence presented here suggests that IS does have the potential to generate regional environmental and economic benefits. However, it is more commonly associated with pre-existing clusters of industries than planned de novo regional developments. Thus, IS should be deployed only with reservations as a weapon in the armoury of regional economic development. Nevertheless, increasing imperatives for regional sustainable economic development may dictate that IS'system-scale approach to resource efficiency receive serious exploration. Further research is needed therefore to examine the lessons from successful IS kernels that are transferable nationally and/or internationally. Important questions for further research include: Given the potential public good from IS, what should be the role of the state in its promotion? What form of policies would be effectively engage business in IS practices, and how would they vary according to geographic context? What is the role of the region in the development of IS? What are the implications of international commodity flows for closed-loop production? How can the scope of IS be broadened to incorporate consumer as well as industrial waste? What would be the role for the existing materials recycling and recovery industries within 
an economy where by-product exchange were increasingly the norm? Whilst there are presently more questions than answers,applying insights from industrial ecology and regional development literatures opens a dialogue between researchers in both fields that should help both move forward toward a better understanding of the complex relationship between development and the environment.

\section{ACKNOWLEDGEMENTS}

We would like to thank all participants in the 2004 AAG sessions on industrial ecology, from which this collection is ultimately derived. We are grateful to Angela Hull, Gail Welsh and the Editorial Board for their support. Thanks to Andy Jonas and anonymous reviewers for their comments on this paper.

\section{REFERENCES}

CHERTOW M.R. (1999) The Eco-industrial park model reconsidered. Journal of Industrial Ecology 2 (3) 8-10.

CHERTOW M.R. (2000) Industrial Symbiosis: Literature and Taxonomy, Annual Review of Energy and Environment 25, 313-337.

CHERTOW M.R. (2007) “Uncovering” industrial symbiosis, Journal of Industrial Ecology 11, 11-30.

CHERTOW M.R., ASHTON W.S. and ESPINOSA J.C. (200?) Industrial Symbiosis in Puerto Rico: Environmentally Related Agglomeration Economies, Regional Studies.

CHIU A.S.F. and YONG G. (2004) on the industrial ecology potential in Asian Developing Countries. Journal of Cleaner Production 12, 1037-1045. 
COHEN-ROSENTHAL E. (2003) What is eco-industrial development? In COHEN-

ROSENTHAL E. and MUSNIKOW J. (Eds) Eco-industrial strategies: unleashing the synergy between economic development and the environment, pp. 14-29. Greenleaf Publishing, Sheffield.

DESCHENES P.J. and CHERTOW M. (2004) An island approach to industrial ecology: towards sustainability in the island context. Journal of Environmental Planning and Management. 47, 201-217.

DESROCHERS P. (2002) Cities and Industrial symbiosis: Some historical perspectives and policy implications, Journal of Industrial Ecology 5, 29-44.

DEUTZ P. and GIBBS D. (200?) Industrial ecology and regional development: Eco-industrial development as cluster policy. Regional Studies.

FROSCH R.A. and GALLOPOULOS N.E. (1989) Strategies for manufacturing, Scientific American 261, 94-102.

GERTLER N. (1995) Industrial Ecosystems: Developing sustainable industrial structures. MSc thesis, MIT. http://www.smartcommunities.ncat.org/business/gertler2.shtml accessed 5.3.07.

GIBBS D. (2003) Trust and networking in inter-firm relations: the case of eco-industrial development, Local Economy, 18, 222-236.

GIBBS D. and DEUTZ P. (2005) Implementing Industrial Ecology? Planning for eco-industrial parks in the USA. Geoforum 36, 452-464.

GIBBS D., DEUTZ P. and PROCTOR A. (2005) Industrial ecology and eco-industrial development: A new paradigm for local and regional development? Regional Studies 39, 171-183.

http://mc.manuscriptcentral.com/cres Email: regional.studies@newcastle.ac.uk 
GRADEL T. and ALLENBY B.R.(1995) Industrial Ecology. Prentice Hall, Englewood Cliffs, N.J.

HAUGHTON G. and COUNSELL D. (2004) Regions, Spatial Strategies and Sustainable Development. Routledge, London

HEERES, RR, VERMEULEN WJV, and DE WALLE, FB (2004) Eco-industrial park initiatives in the USA and the Netherlands: first lessons, Journal of Cleaner Production 12 985-995.

HEWES A.K. and LYONS D.I. (200?) The humanistic side of eco-industrial parks: Champions and the role of trust. Regional Studies.

HUDSON, R. (2007) Region and place: rethinking regional development in the context of global environmental change. Progress in Human Geography, 31(6) 827-836.

KORHONEN J., WIHERSAARI. M., and SAVOLAINEN, I. (1999) Industrial ecology of a regional energy supply system: The case of Jyvaskyla Region. Journal of Greener Management International, 26, 57-67.

LOWE, E.A. (2002) Introduction to Eco-Industrial Parks and Networks. Available from: www.indigodev.com

LOWE, E.A. AND WARREN J. (1996) The source of Value: An Executive Briefing and Sourcebook on Industrial Ecology. Battelle Pacific Northwest Library, Richland, WA. MURPHY J.T. (2006) Building trust in economic space, Progress in Human Geography 30, 427 450.

OH, D-S, K., K-B, KIM and JEONG S-Y (2005) Eco-industrial park design: a Daedeok Technovalley case study. Habitat International 29, 269-284.

PELEGRÍN A. and BOLANCÉ C., (2008) Regional foreign direct investment in manufacturing. Do Agglomeration economies matter? Regional Studies 42(4), 505-522. 
SCHLARB, M. (2001) Eco-industrial Development: A Strategy for Building Sustainable Communities, Cornell University/Washington DC: United States Economic Development Administration.

SCHWARZ E.J. and STEINIGER, K.W. (1997) Implementing nature's lesson: the industrial recycling network enhancing regional development. Journal of Cleaner Production 5, 47-56.

VAN LEEUWEN M.G., VERMEULEN W.J.V. and GLASBERG P. (2003) Planning ecoindustrial parks: an analysis of Dutch methods, Business Strategy and the Environment 12, 147-162.

http://mc.manuscriptcentral.com/cres Email: regional.studies@newcastle.ac.uk 